Research Article

\title{
Use of cassava wastewater in Capsicum chinense production ${ }^{1}$
}

Andrezza Grasielly Costa ${ }^{2}$, Alide Mitsue Watanabe Cova ${ }^{2}$, Luciano da Silva Souza ${ }^{2}$, Francisco Alisson da Silva Xavier ${ }^{3}$, Marcos Roberto Santos Correia ${ }^{2}$, Daniel Ribeiro Gonçalves ${ }^{2}$, Willian Fernandes de Almeida ${ }^{4}$

\section{ABSTRACT}

The use of resources derived from the agricultural property itself to meet the needs of producers promotes the reduction of costs with commercial inputs and recycling of by-products, among them the liquid waste from the cassava flour production, called cassava wastewater, which can be an important fertilization source. This study aimed to evaluate the growth and production of Capsicum chinense Jacq., as a function of cassava wastewater doses associated with mineral fertilizer proportions. The experiment was conducted in a greenhouse, in a completely randomized design, with treatments distributed in a $3 \times 5$ factorial scheme, corresponding to 3 doses $(0,50$ and $100 \%$ ) of the mineral fertilization recommended for the crop and 5 doses $\left(0,25,50,100\right.$ and $\left.150 \mathrm{~m}^{3} \mathrm{ha}^{-1}\right)$ of cassava wastewater, with 4 replicates. The cassava wastewater doses influenced the crop yield, showing a linear trend. The dose of $150 \mathrm{~m}^{3} \mathrm{ha}^{-1}$ promoted a yield equivalent to that obtained with the application of $100 \%$ of the mineral fertilization recommended for this crop, thus enabling the partial or total replacement of this fertilization by cassava wastewater.

KEYWORDS: Manihot esculenta Crantz, liquid waste, chemical fertilizer.

\section{INTRODUCTION}

Peppers are used worldwide for the most diverse purposes. In Brazil, its fresh consumption is quite pronounced in the North and Northeast regions, with the 'Malagueta', 'Tabasco', 'Bode', 'Biquinho', 'Cumari do Pará', 'Habanero' and 'Murupi' cultivars being the most produced ones. Capsicum chinense Jacq. has stood out in the market, due to its peculiar

\section{RESUMO}

\section{Uso de água residuária de mandioca}

na produção de Capsicum chinense

A utilização de recursos derivados da própria propriedade agrícola para suprir necessidades dos produtores proporciona a redução de custos com insumos comerciais e a reciclagem de subprodutos, dentre eles, o resíduo líquido da produção de farinha de mandioca, denominado manipueira, que pode configurar-se como importante fonte de adubação. Objetivou-se avaliar o crescimento e a produção de Capsicum chinense Jacq., em função de doses de manipueira associada a proporções de adubo mineral. O estudo foi conduzido em casa-de-vegetação, em delineamento inteiramente casualizado, com os tratamentos distribuídos em esquema fatorial $3 \times 5$, sendo 3 doses (0, 50 e $100 \%)$ da adubação mineral recomendada para a cultura e 5 doses $(0,25,50,100$ e $150 \mathrm{~m}^{3} \mathrm{ha}^{-1}$ ) de manipueira, com 4 repetições. As doses de manipueira influenciaram na produtividade da cultura, apresentando tendência linear. A dose de $150 \mathrm{~m}^{3} \mathrm{ha}^{-1}$ proporcionou produtividade equivalente à obtida com a aplicação de $100 \%$ da adubação mineral recomendada para essa cultura, permitindo, assim, a substituição parcial ou total dessa adubação pela manipueira.

PALAVRAS-CHAVE: Manihot esculenta Crantz, resíduo líquido, fertilizante químico.

aroma, characteristic flavor and absence of pungency, and can be consumed both fresh and preserved (Heinrich et al. 2015, Julião et al. 2015, Rodrigues 2016).

Peppers should be grown in deep, light, drained and preferably fertile soils, with fertilization recommendations of 40-60 $\mathrm{kg} \mathrm{ha}^{-1}$ of N, 50-600 $\mathrm{kg} \mathrm{ha}^{-1}$ of $\mathrm{P}_{2} \mathrm{O}_{5}$ and $240 \mathrm{~kg} \mathrm{ha}^{-1}$ of $\mathrm{K}_{2} \mathrm{O}$ (Costa \& Henz 2007). For organic fertilization, the recommended amount

\footnotetext{
${ }^{1}$ Received: July 30, 2020. Accepted: Oct. 23, 2020. Published: Nov. 23, 2020. DOI: 10.1590/1983-40632020v5064756.

${ }^{2}$ Universidade Federal do Recôncavo da Bahia, Centro de Ciências Agrárias, Ambientais e Biológicas, Cruz das Almas, BA, Brasil.E-mail/ORCID: andrezza_grasielly@hotmail.com/0000-0002-0296-1716, alidewatanabe@yahoo.com.br/ 0000-0003-0570-7008, 1souza@ufrb.edu.br/0000-0002-6795-7697,marcos_roberto9974@hotmail.com/0000-0002-1404-7710, danielgoncalves724@gmail.com/0000-0003-0675-7218.

${ }^{3}$ Empresa Brasileira de Pesquisa Agropecuária (Embrapa Mandioca e Fruticultura), Cruz das Almas, BA, Brasil. E-mail/ORCID: alisson.xavier@embrapa.br/0000-0002-8141-2343.

${ }^{4}$ Instituto Federal do Espírito Santo, Barra de São Francisco, ES, Brasil. E-mail/ORCID: wifatec@yahoo.com.br/0000-0001-7394-2865.
} 
is $10-30 \mathrm{t} \mathrm{ha}^{-1}$ of aged cattle manure or 2.5-10 $\mathrm{t} \mathrm{ha}^{-1}$ of chicken manure.

Concerning the 2006 agricultural census, the highest pepper yields were obtained in properties fertilized with mineral fertilizers $(7,238 \mathrm{t})$ and with the joint use of mineral and organic fertilizers $(7,108 \mathrm{t})$, followed by only organic fertilizers $(2,977 \mathrm{t})$ and agricultural units that did not use fertilization (1,360 t) (IBGE 2006). Costa et al. (2019) highlighted the importance of using resources derived from the agricultural property itself to meet the needs of producers, promoting the recycling of by-products and reduction of costs with commercial inputs. In this context, the liquid waste from the cassava flour production may be an important source of organic fertilization.

Cassava wastewater is released during the cassava flour production and is characterized by a high organic load, fibers, starch, cyanogenic compounds and nutrients such as nitrogen, phosphorus, potassium, calcium and magnesium (Araújo et al. 2015, Bezerra et al. 2017, Sánchez et al. 2017). In northeastern Brazil, most cassava wastewater is produced in small facilities and discharged directly into the soil, causing aesthetic and environmental inconveniences in the vicinity of flour mills (Araujo \& Lopes 2009, Sánchez et al. 2017).

Among the problems caused by the indiscriminate discharge of the effluent, it is possible to highlight the contamination of surface and underground water and alteration in the soil physical and chemical attributes, in addition to the formation of huge lakes and release of unpleasant odors, attracting rodents and insects (Araujo \& Lopes 2009).

These problems are mainly associated with the large volume of effluents released into the environment. Ponte (2006) describes that, for every $3 \mathrm{~kg}$ of pressed cassava roots, about $1 \mathrm{~L}$ of cassava wastewater is generated. Based on this mean proportion, if the $963,000 \mathrm{t}$ of cassava roots produced in Bahia, in 2019 (IBGE 2019), were processed for flour production, about $321,000 \mathrm{~m}^{3}$ of cassava wastewater would be released.

Studies have been conducted to make use of this effluent efficiently. Vieites (1998), when studying the effects of cassava wastewater replacing mineral fertilization in tomato cultivation, observed that this effluent contributed to increasing the yield, diameter and length of tomato fruits. When using cassava wastewater in bell pepper fertilization, Lima \& Valente (2017) noticed that it promoted significant effects on fruit length and diameter. Araújo et al. (2015), when analyzing the growth and yield of maize fertilized with cassava wastewater doses, reported that this effluent was effective for plant growth. Bezerra et al. (2017) used cassava wastewater as a source of organic fertilizer in 'Marandu' palisade grass pasture and observed that the increase of effluent depths promoted a greater forage biomass and reduction of spontaneous plants.

Thus, the use of cassava wastewater as a fertilizer is an opportunity to simultaneously reduce the problems caused by its indiscriminate disposal around the flour mills, improving the environmental quality and promoting an increase in crop yield and savings with mineral fertilizers.

Therefore, considering its significant organic load and the presence of essential nutrients for plant development, the hypothesis of this study is that cassava wastewater may be used as an organic fertilizer in the cultivation of $C$. chinense, partially or totally replacing the mineral fertilization. Thus, the present study aimed to evaluate the growth and yield of $C$. chinense, as a function of cassava wastewater doses associated with mineral fertilizer proportions.

\section{MATERIAL AND METHODS}

The study was conducted in a greenhouse of the Universidade Federal do Recôncavo da Bahia, in Cruz das Almas, Bahia state, Brazil (12³9'48.84”'S, $39^{\circ} 5^{\prime} 15.17^{\prime \prime} \mathrm{W}$ and altitude of $220 \mathrm{~m}$ ), from May to October 2019. According to the Köppen-Geiger classification, the region has a humid tropical climate (Af), with occurrence of precipitation in almost all months of the year (Alvares et al. 2014).

Plastic pots with capacity of $10 \mathrm{dm}^{3}$ were filled with Latossolo Amarelo Distrocoeso típico (Densic Ferralsol; Oxisol), according to the classification performed by Jacomine et al. (1977) and updated according to Santos et al. (2018), collected in the $0-0.20 \mathrm{~cm}$ layer. The soil classification by WRB/ FAO and Soil Taxonomy is presented between parentheses. The textural composition of the soil was determined by the pipette method, using $1 \mathrm{~mol} \mathrm{~L}^{-1}$ of $\mathrm{NaOH}$ as dispersant (Teixeira et al. 2017). The soil chemical attributes and textural composition were: $\mathrm{pH}=5.1$; electrical conductivity 
of the saturation extract $=0.801 \mathrm{dS} \mathrm{m} \mathrm{m}^{-1} ; \mathrm{P}=$ $13 \mathrm{mg} \mathrm{dm}{ }^{-3} ; \mathrm{K}^{+}=48 \mathrm{mg} \mathrm{dm}{ }^{-3} ; \mathrm{Na}^{+}=0.04 \mathrm{cmol}_{\mathrm{c}} \mathrm{dm}^{-3}$; $\mathrm{Ca}^{2+}=1.0 \mathrm{cmol}_{\mathrm{c}} \mathrm{dm}^{-3} ; \mathrm{Mg}^{2+}=0.5 \mathrm{cmol}_{\mathrm{c}} \mathrm{dm}^{-3} ;$ organic matter $=1.18 \% ; \mathrm{Al}^{3+}=0.2 \mathrm{cmol}_{\mathrm{c}} \mathrm{dm}^{-3} ; \mathrm{H}^{+}+\mathrm{Al}^{3+}=$ $3.0 \mathrm{cmol}_{\mathrm{c}} \mathrm{dm}^{-3}$; sand $=682.5 \mathrm{~g} \mathrm{~kg}^{-1}$; silt $=202.2 \mathrm{~g} \mathrm{~kg}^{-1}$; and clay $=115.3 \mathrm{~g} \mathrm{~kg}^{-1}$ (Teixeira et al. 2017). Dolomitic limestone was added to correct the soil $\mathrm{pH}$ from 5.10 to 6.67 by the incubation method (Novais et al. 2007).

A randomized block design was used, with treatments distributed in a $3 \times 5$ factorial scheme, with four replicates, totaling 60 experimental units, with spacing of $0.50 \mathrm{~m}$ between experimental units and $0.80 \mathrm{~m}$ between blocks. The treatments were randomly distributed in each block. The blocks remained fixed in the same place in the greenhouse throughout the cycle.

The studied factors were 0,50 and $100 \%$ of the mineral fertilization (Costa \& Henz 2007) and 0 , $25,50,100$ and $150 \mathrm{~m}^{3} \mathrm{ha}^{-1}$ of cassava wastewater (Vieites 1998). Thus, the applied treatments were, respectively for mineral fertilization and cassava wastewater: $0 \%$ and $0 \mathrm{~m}^{3} \mathrm{ha}^{-1} ; 0 \%$ and $25 \mathrm{~m}^{3} \mathrm{ha}^{-1}$; $0 \%$ and $50 \mathrm{~m}^{3} \mathrm{ha}^{-1} ; 0 \%$ and $100 \mathrm{~m}^{3} \mathrm{ha}^{-1} ; 0 \%$ and $150 \mathrm{~m}^{3} \mathrm{ha}^{-1} ; 50 \%$ and $0 \mathrm{~m}^{3} \mathrm{ha}^{-1} ; 50 \%$ and $25 \mathrm{~m}^{3} \mathrm{ha}^{-1}$; $50 \%$ and $50 \mathrm{~m}^{3} \mathrm{ha}^{-1} ; 50 \%$ and $100 \mathrm{~m}^{3} \mathrm{ha}^{-1} ; 50 \%$ and $150 \mathrm{~m}^{3} \mathrm{ha}^{-1} ; 100 \%$ and $0 \mathrm{~m}^{3} \mathrm{ha}^{-1} ; 100 \%$ and $25 \mathrm{~m}^{3} \mathrm{ha}^{-1} ; 100 \%$ and $50 \mathrm{~m}^{3} \mathrm{ha}^{-1} ; 100 \%$ and $100 \mathrm{~m}^{3} \mathrm{ha}^{-1} ; 100 \%$ and $150 \mathrm{~m}^{3} \mathrm{ha}^{-1}$.

The fertilizers applied were: urea $\left(40 \mathrm{~kg} \mathrm{ha}^{-1}\right)$; potassium sulfate $\left(180 \mathrm{~kg} \mathrm{ha}^{-1}\right)$; single superphosphate $\left(600 \mathrm{~kg} \mathrm{ha}^{-1}\right)$; boric acid $\left(1 \mathrm{~kg} \mathrm{ha}^{-1}\right)$; and zinc sulfate $\left(30 \mathrm{~kg} \mathrm{ha}^{-1}\right)$. The cassava wastewater application was split into portions, in order to avoid the loss of nutrients with soil saturation.

The cassava wastewater was obtained from a cassava processing mill located in Cruz das Almas, in the Sapucaia community, about $3 \mathrm{~km}$ from the experimental area. The samples were collected directly from the press, transferred to a container with capacity for $50 \mathrm{~L}$ and transported to the experimental area. It is worth mentioning that the container with cassava wastewater was left open and at rest for seven days, at room temperature, for hydrocyanic acid volatilization. A sample of the effluent after the treatment was kept in a refrigerated environment for analysis aimed at its characterization (Table 1).

Capsicum chinense, marketed by ISLA Sementes, was sown in a tray containing coconut fiber and cattle manure at a 3:1 ratio, respectively. Transplanting was performed at 60 days after sowing, when the seedlings had 4-5 developed leaves, planting one plant per pot.

Mercury tensiometers were used for irrigation management, with soil water tension daily readings during the early hours of the morning. Irrigation was carried out with public-supply water, using a graduated cylinder, restoring the moisture to the level equivalent to a $10 \mathrm{kPa}$ tension, in order to meet the water needs of the crop. Manual weeding was performed whenever necessary to keep the crop free of spontaneous plants.

The following growth components were analyzed at 100 days after transplanting (DAT): plant height, stem diameter, number of leaves, leaf area, shoot dry mass and chlorophyll index (total, $a$ and $b$ ). In relation to the production, the number of fruits, yield, fruit fresh mass, length and diameter, fruit tip length and fruit wall thickness were determined. For this, 10 fruits were randomly selected in each treatment, using the mean of the measured values.

The plant height was determined with a millimeter tape, from the plant collar to the apical bud. The number of leaves and number of fruits were obtained by direct counting. The stem diameter and the variables fruit length, fruit diameter, fruit tip length and fruit wall thickness were measured with a digital caliper (accuracy of $0.01 \mathrm{~mm}$ ). The tip length was determined from the point at which the fruit diameter was $0.005 \mathrm{~m}$ up to the thinnest end.

The total yield was obtained by multiplying the fresh fruit mass by the number of plants in

Table 1. Characteristics of cassava wastewater applied in the cultivation of Capsicum chinense.

\begin{tabular}{|c|c|c|c|c|c|c|c|}
\hline $\mathrm{pH}^{(1)}$ & $\begin{array}{c}\mathrm{EC} \\
\mathrm{dS} \mathrm{m}^{-1}\end{array}$ & TDS & $\mathrm{N}$ & $\mathrm{P}$ & $\mathrm{K}$ & $\mathrm{Ca}$ & $\mathrm{Mg}$ \\
\hline $3.71^{(2)}$ & 8.5 & 2,306 & 81.4 & $1,205.9$ & $5,480.4$ & 517.7 & 209.0 \\
\hline $3.71^{(3)}$ & 9.2 & 2,473 & 78.5 & $1,227.7$ & $5,525.8$ & 402.2 & 530.4 \\
\hline
\end{tabular}
(1) $\mathrm{pH}$ : hydrogen potential; EC: electrical conductivity; TDS: total dissolved solids; N: nitrogen; P: phosphorus; K: potassium; Ca: calcium; Mg: magnesium. ${ }^{(2)}$ First
application of cassava wastewater. ${ }^{(3)}$ Second application of cassava wastewater. 
1 hectare, considering the recommended spacing, in a total of 25,000 plants per hectare. The leaf area was determined by the disc method (Camargo 1992). Chlorophyll was measured by indirect readings of leaf chlorophyll, using the portable chlorophyll meter Falker ClorofiLOG ${ }^{\mathrm{TM}} 1030$ (Schlichting et al. 2015). The shoot dry mass, fruit dry mass and fruit fresh mass were determined using a precision scale. The dry masses were obtained after drying in a forced ventilation oven at $65{ }^{\circ} \mathrm{C}$, until reaching a constant weight.

The results obtained for all variables were subjected to analysis of variance and $\mathrm{F}$ test. The means of qualitative variables were subjected to the Tukey test ( $\mathrm{p} \leq 0.05)$ and the means of quantitative variables to regression analysis. The models were chosen according to their significance by the $\mathrm{F}$ test $(\mathrm{p} \leq 0.05)$ and coefficient of determination $\left(\mathrm{R}^{2}\right)$, using the Sisvar software, version 5.6 (Ferreira 2019).

\section{RESULTS AND DISCUSSION}

The applied treatments caused significant differences for plant height ( $\mathrm{p} \leq 0.05$ for mineral fertilization and $\mathrm{p} \leq 0.01$ for cassava wastewater), stem diameter, number of leaves, leaf area, total chlorophyll content, chlorophyll $a$ content and shoot dry mass $(\mathrm{p} \leq 0.01)$ of $C$. chinense at 100 days after transplanting (DAT) (Table 2). Likewise, there was significance for the interaction between mineral fertilization and cassava wastewater doses $(\mathrm{p} \leq 0.05$ or $\mathrm{p} \leq 0.01$ ), except for stem diameter and shoot dry mass.

The treatments that received the mineral fertilizer dose recommended for pepper crop were the most responsive ones, regarding the variables stem diameter (Figure 1A) and shoot dry mass (Figure 1C), at 100 DAT. In relation to the cassava wastewater doses, these variables showed a tendency to increase linearly (Figures 1B and 1D). This is probably related to the composition of the cassava wastewater, due to the abundance of nutrients, especially potassium, an element that has important functions in plant cells and tissues (Kerbauy 2004). In the present study, the cassava wastewater contained essential nutrients for the plant development, especially high concentrations of $\mathrm{K}$ and $\mathrm{P}$ (Table 1).

The decomposition of the significant interaction between mineral fertilization and cassava wastewater for plant height, number of leaves, leaf area, total chlorophyll, chlorophyll $a$ and chlorophyll $b$ of $C$. chinense demonstrated that the treatments were influenced by the maximum dose of cassava wastewater applied with different mineral fertilization proportions (Figure 2).

The plant height increased linearly with the increment in the cassava wastewater doses for the different proportions of mineral fertilization (Figure 2A). Similarly, the number of leaves (Figure 2B) and leaf area (Figure 2C) showed a linear trend with the increment in the cassava wastewater doses. These results demonstrate that the nutrients present in the cassava wastewater (Table 1) promoted beneficial effects for the $C$. chinense; so, it is necessary to carry out studies with higher doses to evaluate the maximum potential of the crop.

The variables total chlorophyll (Figure 2D), chlorophyll $a$ (Figure 2E) and chlorophyll $b$ (Figure $2 \mathrm{~F}$ ) showed a negative linear trend as the cassava wastewater doses increased, with significance only for

Table 2. Summary of the analysis of variance with the respective mean squares for the variables plant height (PH), stem diameter (SD), number of leaves (NL), leaf area (LA), total chlorophyll (TC), chlorophyll $a$ (Chla), chlorophyll $b$ (Chl $b)$ and shoot dry mass (SDM) of Capsicum chinense at 100 days after transplanting, grown under mineral fertilizer (MF) proportions recommended for the crop and cassava wastewater $(\mathrm{CW})$ doses.

\begin{tabular}{|c|c|c|c|c|c|c|c|c|c|}
\hline SV & $\mathrm{DF}$ & $\begin{array}{l}\mathrm{PH} \\
\mathrm{cm}\end{array}$ & $\begin{array}{l}\text { SD } \\
\mathrm{mm}\end{array}$ & NL & $\begin{array}{l}\text { LA } \\
\mathrm{cm}^{2}\end{array}$ & $\begin{array}{c}\text { TC } \\
\text { FCI }\end{array}$ & $\begin{array}{c}\text { Chla } \\
\text { FCI }\end{array}$ & $\begin{array}{c}\text { Chl } b \\
\text { FCI }\end{array}$ & $\begin{array}{c}\text { SDM } \\
\mathrm{g}\end{array}$ \\
\hline Block & 3 & $10.69^{\mathrm{ns}}$ & $1.76^{\mathrm{ns}}$ & $467.55^{\mathrm{ns}}$ & $27.74^{\mathrm{ns}}$ & $1.37^{\mathrm{ns}}$ & $0.65^{\mathrm{ns}}$ & $0.33^{\text {ns }}$ & $5.71^{\mathrm{ns}}$ \\
\hline MF & 2 & $27.30^{*}$ & $7.39 * *$ & $1,505.12 * *$ & $184.58 * *$ & $57.29 * *$ & $38.54 * *$ & $2.06^{\mathrm{ns}}$ & $48.13^{* *}$ \\
\hline $\mathrm{CW}$ & 4 & $287.71 * *$ & $16.60 * *$ & $12,276.96^{* *}$ & $262.83 * *$ & $90.43 * *$ & $51.93 * *$ & $5.36 * *$ & $113.16^{* *}$ \\
\hline $\mathrm{MF} \times \mathrm{CW}$ & 8 & $23.88 * *$ & $1.13^{\mathrm{ns}}$ & $2,326.58^{* *}$ & $58.74 *$ & $21.12 * *$ & $9.93 * *$ & $2.42 * *$ & $4.84^{\mathrm{ns}}$ \\
\hline Residual & 42 & 7.21 & 0.63 & 219.99 & 23.56 & 3.71 & 1.72 & 0.67 & 3.52 \\
\hline Mean & - & 56.21 & 11.65 & 201.67 & 57.17 & 35.61 & 28.09 & 7.49 & 31.01 \\
\hline$\overline{\mathrm{CV}(\%)}$ & - & 4.78 & 6.79 & 7.35 & 8.49 & 5.41 & 4.68 & 10.98 & 6.05 \\
\hline
\end{tabular}

CV: coefficient of variation; SV: source of variation; DF: degree of freedom; FCI: Falker chlorophyll index; ${ }^{\text {ns }}$ not significant; ${ }^{*}$ significant at $\mathrm{p} \leq 0.05 ; * *$ significant at $\mathrm{p} \leq 0.01$. 


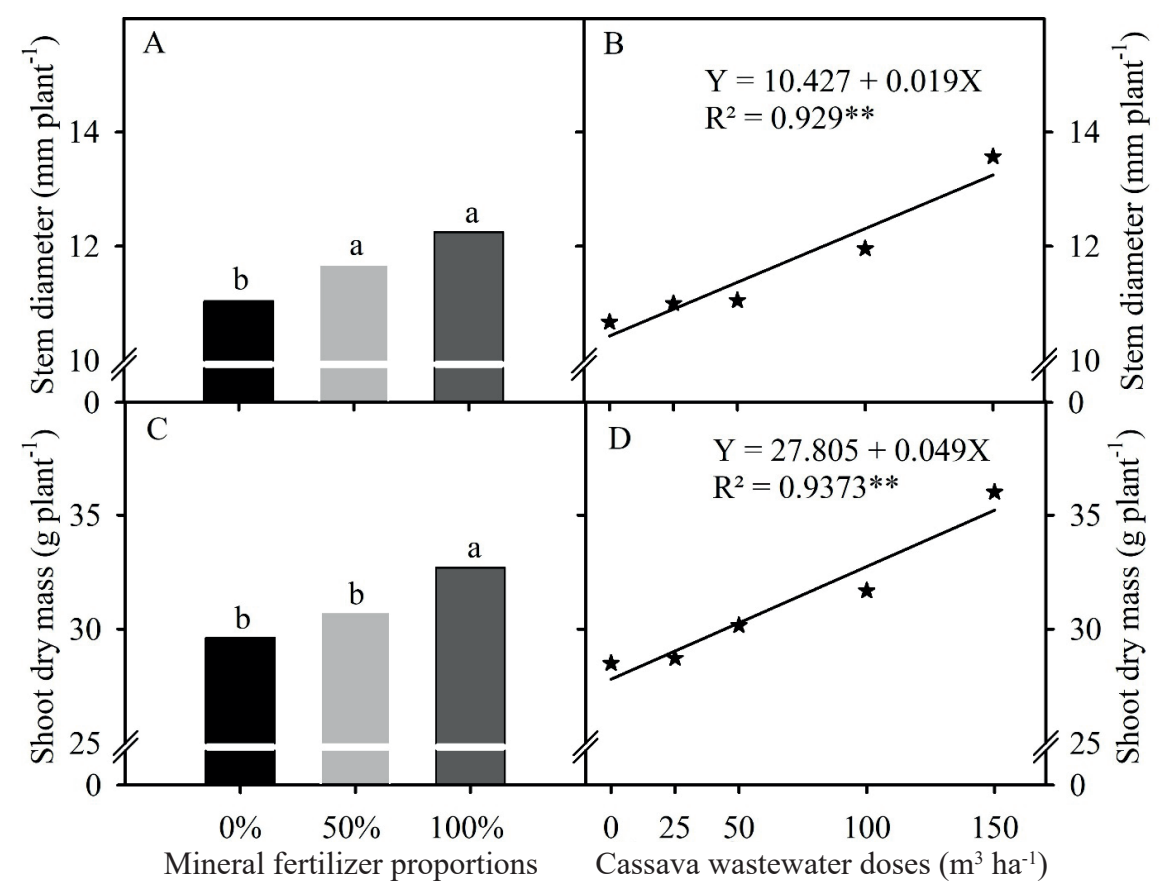

Figure 1. Means for stem diameter (A and B) and shoot dry mass (C and D) of Capsicum chinense at 100 days after transplanting, under mineral fertilizer proportions and cassava wastewater doses, respectively.

the treatments with absence of mineral fertilization. Nitrogen deficiency induces a lower chlorophyll content, because it is a constituent of the molecule. Pagliarini et al. (2014) described that the reduction in the chlorophyll content of $C$. chinense may be associated with nitrogen leaching along the cycle. In addition, there may be nitrogen immobilization by microorganisms.

Regarding the variables yield and fruit wall thickness, the analysis of variance showed a significant effect $(p \leq 0.01)$ for the factors mineral fertilization and cassava wastewater, individually, with no significant effect for the interactions between them (Table 3).
It was possible to observe that the different proportions of mineral fertilizer alone influenced the crop yield, with a $52 \%$ increase under $50 \%$ of the recommended fertilization and $120 \%$ increase under the full dose, if compared to the treatments that did not receive fertilization (Figure 3A). The cassava wastewater doses influenced the crop yield, which showed a linear trend (Figure 3B). According to Vieites (1998), the increase in yield is related to the chemical composition of the cassava wastewater, as it contains approximately $92.98 \%$ of water, facilitating the direct absorption of nutrients such as potassium, nitrogen, phosphorus and calcium.

Table 3. Summary of analysis of variance with the respective mean squares for the variables number of fruits (NF), yield (Y), fruit fresh mass (FFM), fruit dry mass (FDM), fruit length (FL), fruit diameter (FD), fruit tip length (FTL) and fruit wall thickness (FWT) of Capsicum chinense at 100 days after transplanting, under proportions of mineral fertilizer (MF) recommended for the crop and cassava wastewater $(\mathrm{CW})$ doses.

\begin{tabular}{|c|c|c|c|c|c|c|c|c|c|}
\hline SV & DF & NF & $\begin{array}{c}\mathrm{Y} \\
\mathrm{t} \mathrm{ha}^{-1}\end{array}$ & FFM & FDM & FL & FD & FTL & FWT \\
\hline Block & 3 & $189.00 * *$ & $4.12^{\mathrm{ns}}$ & $0.02^{\text {ns }}$ & $0.00^{\mathrm{ns}}$ & $0.12^{\mathrm{ns}}$ & $6.14^{*}$ & $3.64^{\mathrm{ns}}$ & $0.69 * *$ \\
\hline $\mathrm{MF}$ & 2 & $18,084.20 * *$ & $51.22 * *$ & $0.78 * *$ & $0.01 * *$ & $28.91 * *$ & $0.81^{\mathrm{ns}}$ & $1.49^{\mathrm{ns}}$ & $0.57 * *$ \\
\hline CW & 4 & $4,476.36^{* *}$ & $24.13 * *$ & $2.35 * *$ & $0.03 * *$ & $56.54 * *$ & $23.51 * *$ & $9.34 * *$ & $0.66^{* *}$ \\
\hline $\mathrm{MF} \times \mathrm{CW}$ & 8 & $292.72 * *$ & $0.32^{\mathrm{ns}}$ & $0.17 * *$ & $0.00 * *$ & $29.39 * *$ & $4.94 *$ & $6.16^{* *}$ & $0.08^{\mathrm{ns}}$ \\
\hline Residual & 42 & 71.95 & 1.52 & 0.02 & 0.01 & 5.59 & 2.03 & 1.64 & 0.07 \\
\hline Mean & - & 83.30 & 4.18 & 2.07 & 0.30 & 27.39 & 15.62 & 6.39 & 2.41 \\
\hline CV (\%) & - & 10.18 & 29.46 & 7.31 & 6.15 & 8.63 & 9.12 & 20.03 & 10.47 \\
\hline
\end{tabular}

$\mathrm{CV}$ : coefficient of variation; SV: source of variation; DF: degree of freedom; ${ }^{\text {ns }}$ not significant; $*$ significant at $\mathrm{p} \leq 0.05 ; * *$ significant at $\mathrm{p} \leq 0.01$. 


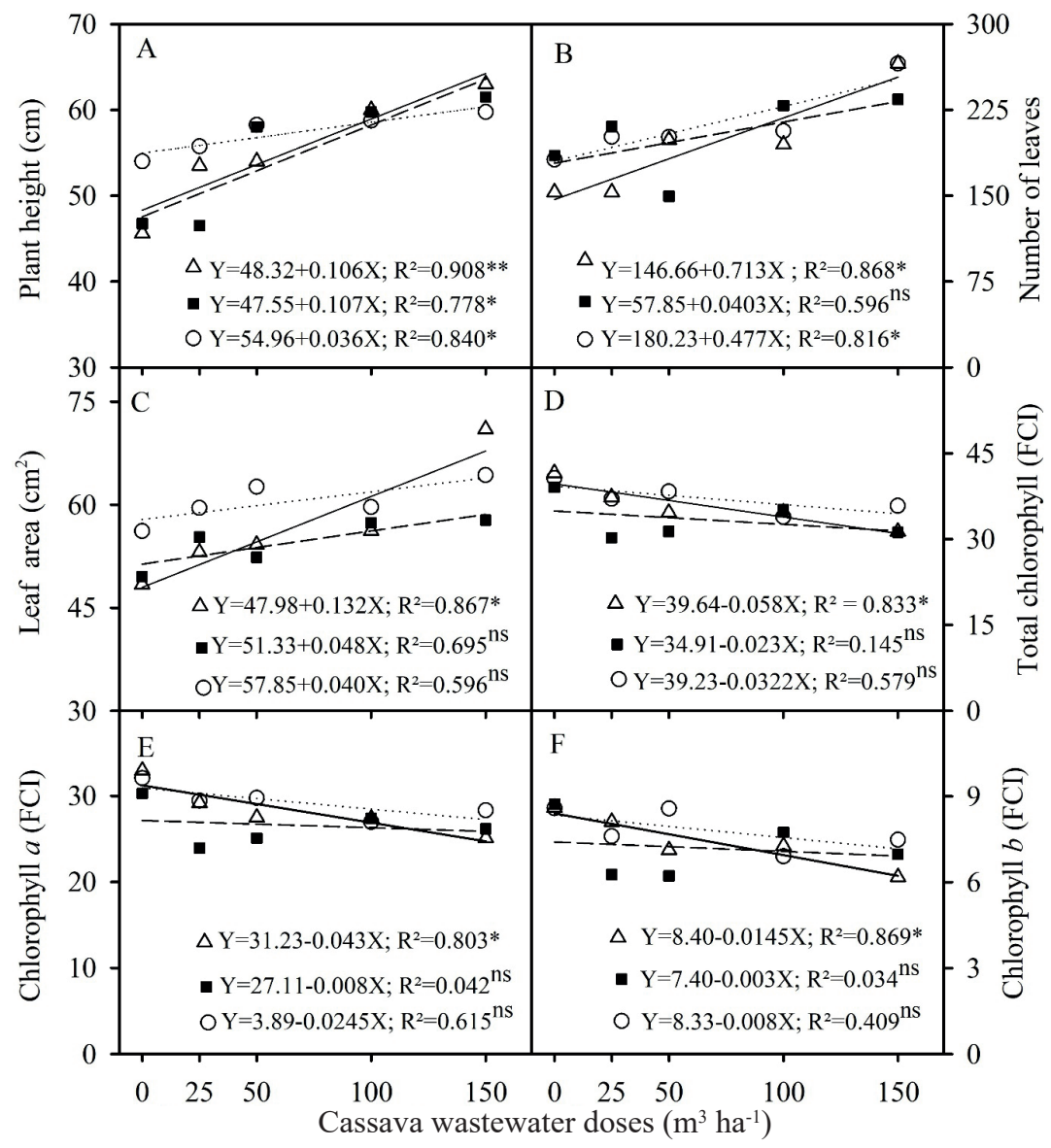

Figure 2. Plant height (A), number of leaves (B), leaf area (C) and contents of total chlorophyll (D), chlorophyll $a$ (E) and chlorophyll $b(\mathrm{~F})$ in Capsicum chinense plants, in the interaction of cassava wastewater doses with the addition of $0(\Delta), 50(\mathbf{\square})$ and $100 \%(\circ)$ of the mineral fertilizer recommended for the crop, at 100 days after transplanting.

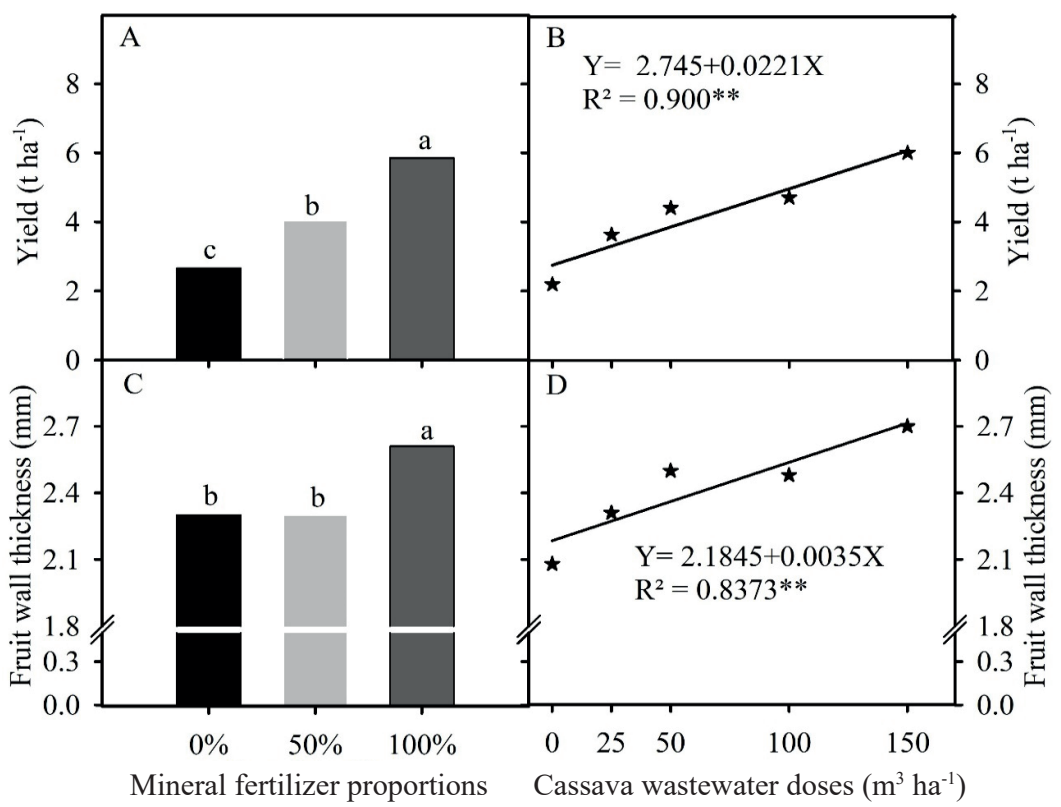

Figure 3. Means of yield (A and B) and fruit wall thickness (C and D) of Capsicum chinense under mineral fertilizer proportions and cassava wastewater doses, respectively, at 100 days after transplanting. 
For fruit wall thickness, there was no difference between the treatments with 0 and $50 \%$ of mineral fertilization, and the dose of $100 \%$ stood out (Figure $3 \mathrm{C}$ ). On the other hand, the cassava wastewater promoted a linear increase, with thickness of $2.7 \mathrm{~mm}$ in the treatments that received $150 \mathrm{~m}^{3} \mathrm{ha}^{-1}$ of cassava wastewater (Figure 3D). Abud et al. (2018) reported that the fruit wall thickness is an important characteristic, especially when it comes to fruits consumed fresh, because fruits with thicker walls are more resistant to postharvest treatments. Jorge et al. (2018) recorded values for peel thickness, according to the maturity stage of $C$. chinense, and found values of $1.30 \mathrm{~mm}$ for green fruits, $1.80 \mathrm{~mm}$ for orangecolored fruits and $2.04 \mathrm{~mm}$ for red fruits, that is, fully ripe. According to these authors, ripe fruits are more turgid due to their higher water content. Therefore, the fruits may have a larger diameter and higher fresh mass, as observed in the present study.
By analyzing the decomposition of the interaction for number of fruits (Figure 4A), it was possible to observe a linear increase with the increase in the cassava wastewater doses, as a function of the fertilizer proportions, with a certain parallelism among the three regressions, with lower values for the dose of $0 \%$ and higher values for $100 \%$. For the bell pepper crop, there was a linear reduction in the number of fruits with the increase in the cassava wastewater doses $(0,20,40,60$ and $80 \mathrm{~mL}$ ) applied weekly in the holes (Lima \& Valente 2017).

The variable fruit length (Figure 4B) showed a quadratic trend for the treatments with absence of mineral fertilizer, with an ideal dose estimated at $102 \mathrm{~m}^{3} \mathrm{ha}^{-1}$ of cassava wastewater, and linear trend for treatments with $100 \%$ of the fertilization recommended for the crop, promoting an increase of approximately $0.018 \mathrm{~mm}$ for each increment in the dose.

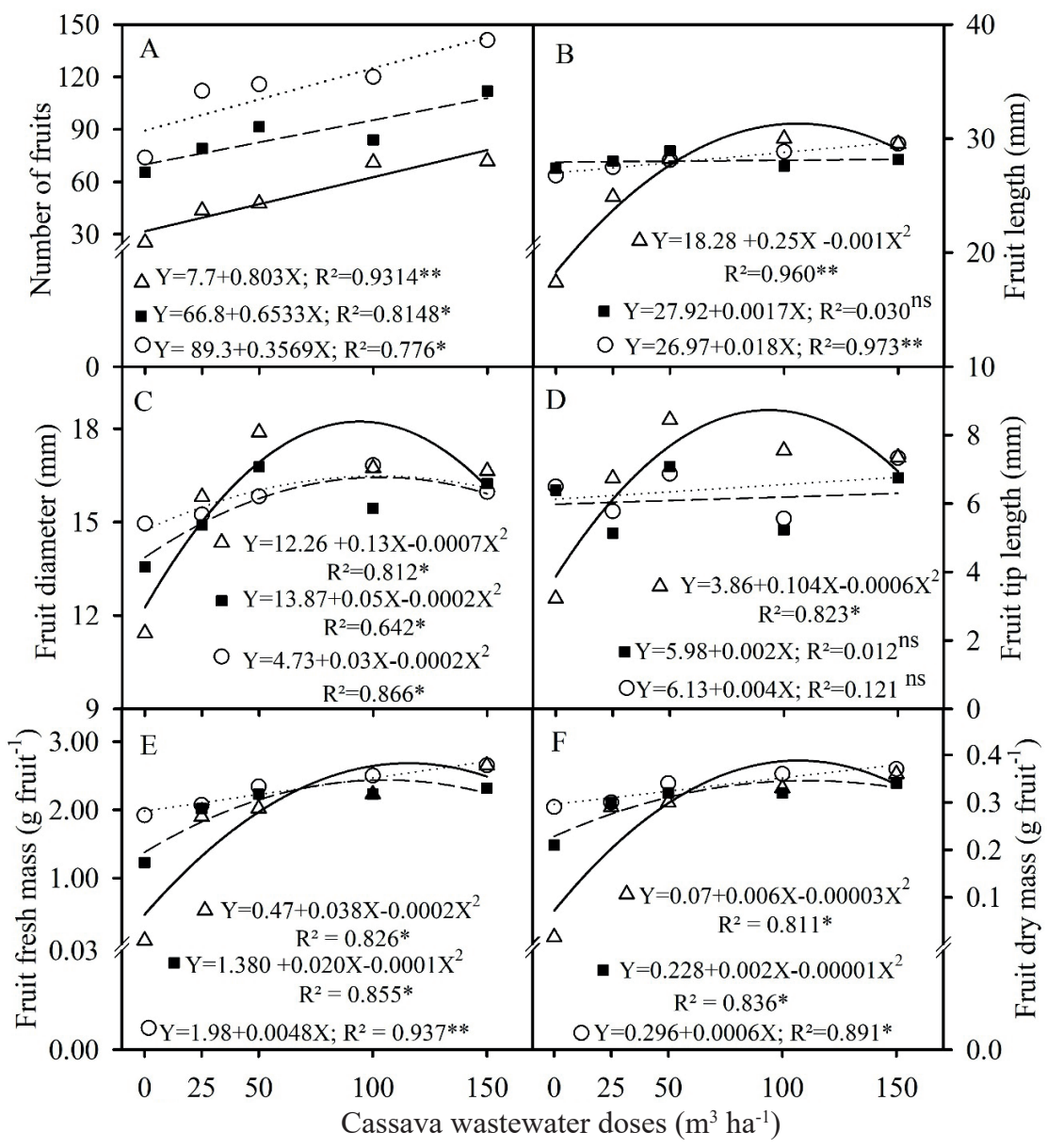

Figure 4. Number of fruits (A), fruit length (B), fruit diameter (C), fruit tip length (D), fruit fresh mass (E) and fruit dry mass (F)

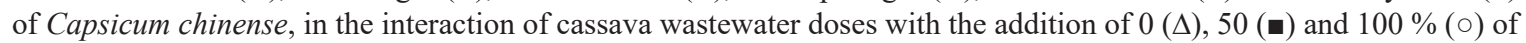
the mineral fertilizer recommended for the crop, at 100 days after transplanting. 
Regarding the fruit diameter (Figure 4C), there was a quadratic trend for the applied doses, as a function of the fertilizer proportions. According to the derivative of the regression equation, the ideal dose for application of only cassava wastewater was equivalent to $91 \mathrm{~m}^{3} \mathrm{ha}^{-1}$, for a maximum fruit diameter of $18.0 \mathrm{~mm}$. For $100 \%$ mineral fertilization, the ideal dose estimated was $86 \mathrm{~m}^{3} \mathrm{ha}^{-1}$, for a maximum fruit diameter of $16.2 \mathrm{~mm}$. For the bell pepper crop, Lima \& Valente (2017) observed a quadratic trend in fruit diameter, as a function of the increase in the cassava wastewater doses $(0,20,40,60$ and $80 \mathrm{~mL})$, with an ideal dose of $16 \mathrm{~mL}$.

Vieites (1998) describes that the increase in fruit diameter and length with the increase in the cassava wastewater doses is probably related to their potassium content, due to its role in the translocation of carbohydrates, and also to the large amount of calcium, which contributes to preserving the integrity and functionality of cell membranes and maintaining a firm tissue consistency.

The fruit tip length (Figure 4D) showed significance only for the absence of mineral fertilization, with a quadratic trend and an ideal dose equivalent to $87 \mathrm{~m}^{3} \mathrm{ha}^{-1}$ of cassava wastewater, with an estimated length of $8.4 \mathrm{~mm}$. A study conducted by Heinrich et al. (2015) recorded a variation of $1.5-6.3 \mathrm{~mm}$ in the fruit tip length in self-fertilized salmon-colored $C$. chinense.

The variable fruit fresh mass (Figure 4E) was influenced by the cassava wastewater doses and mineral fertilization proportions. A linear trend was observed for the treatments subjected to $100 \%$ of mineral fertilization, with a mean increase of $0.18 \mathrm{~g}$ with the increase in the doses, and a quadratic trend was observed for 0 and $50 \%$ of mineral fertilization, with an ideal dose of $100 \mathrm{~m}^{3} \mathrm{ha}^{-1}$ of cassava wastewater, which led to a fruit fresh mass of 2.47 and $2.39 \mathrm{~g}$, respectively. Abud et al. (2018) observed a fruit fresh mass of $1.29 \mathrm{~g}$ for $C$. chinense, and this value decreased as the fruits ripened. Bione (2017) obtained a fruit fresh mass equivalent to $1.6 \mathrm{~g}$ per ripe fruit, in the hydroponic cultivation of $C$. chinense, for the control treatment (composed of public-supply water and nutrient solution). Thus, it was observed that plants under mineral fertilizer doses of 50 and $100 \%$ with the addition of $100 \mathrm{~m}^{-3} \mathrm{ha}^{-1}$ of cassava wastewater produced peppers with superior fresh mass per fruit, even under ideal hydroponic system conditions.
The fruit dry mass (Figure 4F) showed a linear trend for full fertilization (100\%) and a quadratic trend for 0 and $50 \%$ of mineral fertilization. According to the derivative of the regression equation, for $50 \%$ of mineral fertilization the ideal dose of cassava wastewater was equivalent to $105 \mathrm{~m}^{3} \mathrm{ha}^{-1}$, promoting a dry mass of $0.34 \mathrm{~g}$, and to $98 \mathrm{~m}^{3} \mathrm{ha}^{-1}$ for treatments in the absence of mineral fertilization, with an estimated dry mass of $0.36 \mathrm{~g}$ per fruit. Abud et al. (2018) evaluated $C$. chinense fruits at different maturity stages and found a mean value of $0.18 \mathrm{~g}$ per fruit. These authors reported that there is loss of water during the fruit maturation through transpiration, especially at the end of this process, favoring the reduction in the weight of ripe fruits.

\section{CONCLUSION}

The single application of cassava wastewater, at a dose of $150 \mathrm{~m}^{3} \mathrm{ha}^{-1}$, promotes an yield of Capsicum chinense equivalent to that obtained with the application of $100 \%$ of the mineral fertilization recommended for this crop, thus enabling the partial or total replacement of this fertilization with cassava wastewater.

\section{ACKNOWLEDGMENTS}

We thank the Fundação de Amparo à Pesquisa do Estado da Bahia (Fapesb), Coordenação de Aperfeiçoamento de Pessoal de Nível Superior (Capes), Conselho Nacional de Desenvolvimento Científico e Tecnológico (CNPq) and Universidade Federal do Recôncavo da Bahia, for the financial support over the years.

\section{REFERENCES}

ABUD, H. F.; ARAUJO, R. F.; PINTO, C. M. F.; ARAUJO, F. E.; ARAUJO, A. V.; SANTOS, J. A. Caracterização morfométrica dos frutos de pimentas malagueta e biquinho. Revista Brasileira de Agropecuária Sustentável, v. 8, n. 2, p. 29-39, 2018.

ALVARES, C. A.; STAPE, J. L.; SENTELHAS, P. C.; GONÇALVES, J. L. M.; SPAROVEK, G. Köppen's climate classification map for Brazil. Meteorologische Zeitschrift, v. 22, n. 6, p. 711-728, 2014.

ARAUJO, J. S. P.; LOPES, C. A. Produção de farinha de mandioca na agricultura familiar. Niterói: Programa Rio Rural, 2009. 
ARAÚJO, N. C.; OLIVEIRA, S. J. C.; FERREIRA, T. C.; LIMA, V. L. A.; QUEIROZ, A. J. P.; ARAÚJO, F. A. C. Crescimento e produtividade de milho fertilizado com manipueira como fonte alternativa de nutrientes. Revista Tecnologia \& Ciência Agropecuária, v. 9, n. 2, p. 31-35, 2015.

BEZERRA, M. G. S.; SILVA, G. G. C.; DIFANTE, G. S.; EMERENCIANO NETO, J. V.; OLIVEIRA, E. M. M.; OLIVEIRA, L. E. C. Cassava wastewater as organic fertilizer in 'Marandu' grass pasture. Revista Brasileira de Engenharia Agrícola e Ambiental, v. 21, n. 6, p. 404409, 2017.

BIONE, M. A. A. Cultivo hidropônico de pimenteira 'Biquinho' com águas salobras. 2017. Tese (Doutorado em Engenharia Agrícola) - Universidade Federal do Recôncavo da Bahia, Cruz das Almas, 2017.

CAMARGO, A. Efeitos do ácido giberélico no crescimento invernal de dois cultivares de alfafa (Medicago sativa L.), sob condições de casa de vegetação. 1992. Tese (Doutorado em Fitotecnia) - Universidade Estadual Paulista Júlio de Mesquita Filho, Rio Claro, 1992.

COSTA, C. S. R.; HENZ, G. P. Pimenta (Capsicum spp.). Brasília, DF: Embrapa, 2007.

COSTA, R. S.; OLIVEIRA, L. K. B.; SANTOS, J. L. G.; AMORIM, A. V.; CÁ, J.; RIBEIRO, M. C. C.; MESQUITA, R. O.; BRAGA, M. M. Evaluation of different organic fertilizers in the sustainable cultive of coriander. Journal of Agricultural Science, v. 11, n. 6, p. 299-307, 2019.

FERREIRA, D. F. Sisvar: a computer analysis system to fixed effects split plot type designs. Revista Brasileira de Biometria, v. 37, n. 4, p. 529-535, 2019.

HEINRICH, A. G.; FERRAZ, R. M.; RAGASSI, C. F.; REIFSCHNEIDER, F. J. B. Caracterização e avaliação de progênies autofecundadas de pimenta biquinho salmão. Horticultura Brasileira, v. 33, n. 4, p. 465-470, 2015.

INSTITUTO BRASILEIRO DE GEOGRAFIA E ESTATÍSTICA (IBGE). Área plantada, área colhida, quantidade produzida, rendimento médio e valor da produção das lavouras temporárias. 2006. Available at: https://sidra.ibge.gov.br/tabela/1618. Access on: Feb. 2020.

INSTITUTO BRASILEIRO DE GEOGRAFIA E ESTATÍSTICA (IBGE). Área plantada, área colhida, quantidade produzida, rendimento médio e valor da produção das lavouras. 2019. Available at: https://sidra. ibge.gov.br/tabela/1618. Access on: Feb. 2020.

JACOMINE, P. K. T.; CAVALCANTI, A. C.; SILVA, F. B. R.; MONTENEGRO, J. O.; FORMIGA, R. A.; BURGOS, N.; MELO FILHO, H. F. de. Levantamento exploratório: reconhecimento de solos da margem direita do Rio São Francisco, Estado da Bahia. Recife: Embrapa-SNLCS, 1977. (Boletim técnico, 52).
JORGE, E. V. C.; DAVID, A. M. S. S.; FIGUEIREDO, J. C.; BERNARDINO, D. L. M. P.; SILVA, R. A. N.; ALVES, R. A. Estádio de maturação e repouso pós-colheita dos frutos na qualidade de sementes de pimenta biquinho. Revista de Ciências Agrárias, v. 61, n. 1, p. 1-7, 2018.

JULiÃO, L.; SALES, C. C. N.; RASERA, G. B.; STRANGUETTI, M. P. Ervas e especiarias: o complemento que faz toda a diferença. Hortifruti Brasil, v. 14, n. 147, p. 10-18, 2015.

KERBAUY, G. B. Fisiologia vegetal. Rio de Janeiro: Guanabara-Koogan, 2004.

LIMA, A. S. T.; VALENTE, E. C. N. Uso de manipueira na adubação do pimentão. Revista Craibeiras de Agroecologia, v. 1, n. 1, p. 1-3, 2017.

NOVAIS, R. F.; ALVAREZ V., V. H.; BARROS, N. F.; FONTES, R. L. F.; CANTARUTTI, R. B.; NEVES, J. C. L. Fertilidade do solo. Viçosa: Sociedade Brasileira de Ciência do Solo, 2007.

PAGLIARINI, M. K.; CASTILHO, R. M.; MARIANO, F. A. C. Desenvolvimento de mudas de pimenta de bico em diferentes fertilizantes. Revista Brasileira de Horticultura Ornamental, v. 20, n. 1, p. 35-42, 2014.

PONTE, J. J. Cartilha da manipueira: uso do composto como insumo agrícola. Fortaleza: Banco do Nordeste do Brasil, 2006.

RODRIGUES, P. Pimenta: de todos os sabores e gostos. A Lavoura, v. 119, n. 716, p. 8-25, 2016.

SÁNCHEZ, A. S.; SILVA, Y. L.; KALID, R. A.; COHIM, E.; TORRES, E. A. Waste bio-refineries for the cassava starch industry: new trends and review of alternatives. Renewable and Sustainable Energy Reviews, v. 73, n. 1, p. 1265-1275, 2017.

SANTOS, H. G. dos; JACOMINE, P. K.; ANJOS, L. H. C. dos; OLIVEIRA, V. A. de; LUMBRERAS, J. F.; COELHO, M. R.; ALMEIDA, J. A. de; ARAÚJO FILHO, J. C.; OLIVEIRA, J. B. de; CUNHA, T. J. F. Sistema brasileiro de classificação de solos. Brasília, DF: Embrapa, 2018.

SCHLICHTING, A. F.; BONFIM-SILVA, E. D.; SILVA, M. C.; PIETRO-SOUZA, W.; SILVA, T. J. A.; FARIAS, L. N. Efficiency of portable chlorophyll meters in assessing the nutritional status of wheat plants. Revista Brasileira de Engenharia Agrícola e Ambiental, v. 19, n. 12, p. 11481151, 2015.

TEIXEIRA, P. C.; DONAGEMMA, G. K.; FONTANA, A.; TEIXEIRA, W. G. Manual de métodos de análise de solo. Brasília, DF: Embrapa, 2017.

VIEITES, R. L. Efeitos da adubação com manipueira sobre o rendimento e qualidade dos frutos de tomate. Pesquisa Agropecuária Brasileira, v. 33, n. 8, p. 1239-1243, 1998. 